\title{
Robotic milking: Feeding strategies and economic returns ${ }^{1}$
}

\author{
Alex Bach* ${ }^{2}$ and Victor Cabrerał \\ *Institució Catalana de Recerca i Estudis Avançats (ICREA), Barcelona 08010, Spain \\ †Department of Ruminant Production, IRTA (Institut de Recerca i Tecnologia Agroalimentàries), Torre Marimon, Caldes de Montbui, 08140, \\ Barcelona, Spain \\ łDepartment of Dairy Science, University of Wisconsin, Madison 53706
}

\section{ABSTRACT}

Cows in herds equipped with conventional milking parlors follow a structured, consistent, and social milking and feeding routine. Furthermore, in most cases cows in conventional herds receive all their nutrients from a total mixed ration, whereas in herds equipped with robotic or automatic milking systems (AMS) a fraction of their nutrients is provided during milking, mainly as a means to attract cows to the milking system. In this regards, AMS present both a challenge and an opportunity for feeding cows. The main challenge resides in maintaining a minimum and relatively constant milking frequency in AMS. However, milking frequency is dependent on many factors, including the social structure of the herd, the farm layout design, the type of traffic imposed to cows, the type of flooring, the health status of the cow (especially lameness, but also mastitis, metritis, among others), the stage of lactation, the parity, and the type of ration fed at the feed bunk and the concentrate offered in the AMS. Uneven milk frequency has been associated with milk losses and increased risk of mastitis, but most importantly it is a lost opportunity for milking the cow and generating profit. On the other hand, the opportunity from AMS resides in the possibility of milking more frequently and feeding cows more precisely or more closely to their nutrient needs on an individual basis, potentially resulting in a more profitable production system. But, feeding cows in the parlor or AMS has many challenges. On one side, feeding starchy, highly palatable ingredients in large amounts may upset rumen fermentation or alter feeding behavior after milking, whereas feeding highfiber concentrates may compromise total energy intake and limit milking performance. Nevertheless, AMS (and some milking parlors, especially rotary ones) offer

\footnotetext{
Received July 3, 2016.

Accepted December 17, 2016.

${ }^{1}$ Presented as part of the Robotic Dairying: Adapting Farm and Business Management Symposium at the ADSA-ASAS Joint Annual Meeting, Salt Lake City, Utah, July 2016.

${ }^{2}$ Corresponding author: alex.bach@icrea.cat
}

the possibility of feeding the cows to their estimated individual nutrient needs by combining different feeds on real time with the aim of maximizing profits rather than milk yield. This approach requires that not only the amount of feed offered to each cow but also the composition of the feed vary according to the different nutrient needs of the cows. This review discusses the opportunities and pitfalls of milking and feeding cows in an AMS and summarizes different feeding strategies to maximize profits by managing the nutrition of the cows individually.

Key words: automated milking system, feeding strategies, optimization, precision, robotic milking

\section{INTRODUCTION}

Since the first commercial systems appeared in 1992, automatic milking systems (AMS) have been installed at an increasing rate. From that time until 2011, AMS were installed on $>10,000$ farms worldwide (de Koning, 2011). Cows in herds equipped with conventional milking parlors are kept under a structured, consistent, and social milking and feeding routine. Furthermore, in most cases, cows obtain all their nutrients from a TMR; however, in herds equipped with robotic or AMS, a fraction of their nutrients is provided during milking, mainly as a means to attract cows to the milking system, whereas the remaining fraction is supplied in the feed bunk through a partial mixed ration (PMR). Because of this, the AMS presents both a challenge and an opportunity for feeding cows. The main challenge resides in the fact milking frequency in the AMS is dependent not only on the nutritional offer (in terms of both composition and amount) at the AMS (Halachmi et al., 2005; Bach et al., 2007a) but also on many other aspects, including the social structure of the herd (Bach et al., 2006; Melin et al., 2006), the farm layout design (Thune et al., 2002; Halachmi, 2004), the type of traffic imposed to cows (Hermans et al., 2003), and the health condition of the cow, especially lameness (Bach et al., 2007b; Borderas et al., 2008). Uneven milking frequency has been associated with increased risk of mastitis 
(Stefanowska et al., 2000) and decreased daily milk yield, especially in multiparous cows (Bach and Busto, 2005). Furthermore, after an omitted or failed milking, cows stand longer in cubicles and lay less than cows that are successfully milked (Stefanowska et al., 2000), which may potentially increase the risk of lameness; the latter, in turn, may affect the number of visits to the AMS (Spörndly and Wredle 2002; Bach et al., 2007b). On the other hand, opportunity from AMS resides in the possibility of milking more frequently, assigning different milking frequencies to different cows, and feeding cows more precisely or closely to their nutrient needs, potentially resulting in improved feed efficiency and economic returns rendering a more profitable production system than when using a single TMR. This article summarizes and discusses the literature regarding feeding cows in an AMS in an attempt to overcome the challenges and capture the opportunities of an AMS by considering behavioral, nutritional, and economic aspects.

\section{SOCIAL, BEHAVIORAL, AND TRAFFIC CONSIDERATIONS}

Maximum return on the investment of an AMS is attained, in theory, when cows adapt their own daily routine and traffic around the system resulting in full utilization of the AMS with little or no human intervention. Under typical situations, most (67\%) cows milked in AMS have milking intervals between 6 to 12 $\mathrm{h}$, with $11 \%$ of intervals $<6 \mathrm{~h}$ and $21.5 \%$ surpassing 12 h (Gygax et al., 2007). A Canadian survey reported that 4 to $25 \%$ of the cows had to be fetched to the AMS for milking (Rodenburg and House, 2007). The number of cows that need to bed fetched into the AMS bears important economic costs both from a labor and a loss of production stand points, and it typically voids the expected profits (i.e., reduced labor and increased milk yield) behind the decision of installing an AMS. A relatively recent study conducted in the Netherlands (Steeneveld et al., 2012) concluded that herds with AMS have greater capital costs per unit of milk produced over conventional herds, but both types of herds have similar labor costs (thus, the apparent labor savings associated with AMS did not take place in practice). Nevertheless, maximizing milking frequency and minimizing the need to fetch cows to an AMS are pivotal aspects to make AMS profitable. However, one of the largest challenges with AMS is to obtain a consistent milking frequency of cows throughout time. It is not difficult to find herds with an average number of milkings per cow and day of about 2.5 (Wagner-Storch et al., 2003; Bach et al., 2009; Deming et al., 2013); although, in some instances, individual variation in the number of milkings can be high. This aspect makes the design of a feeding program difficult, because if, for instance, milking frequency decreases, the amount of concentrate that the cow will be able to consume in the AMS will also decrease. To minimize variation in milking frequency, it has been proposed to attract cows to the AMS using palatable feeds or impose cows to what is known as forced or guided traffic, which consists on forcing the cows to visit the AMS before they can reach the feed bunk. However, Halachmi et al. (2005) compared milking frequency when limiting concentrate delivery at each milking to $1.2 \mathrm{~kg}$ versus a maximum allowance of $7 \mathrm{~kg} / \mathrm{d}$ and reported no differences in the number of voluntary visits to the AMS. Similarly, Bach et al. (2007a) compared a concentrate allowance of 3 or $8 \mathrm{~kg} / \mathrm{d}$ and reported no differences in the number of daily visits to the AMS. Thus, using large amounts of feed to improve milking frequency does not seem an effective strategy, and some authors have been able to effectively milk cows on pasture with as little as 300 $\mathrm{g}$ of concentrate per visit (Scott et al., 2014) or even without supplementing concentrate in an AMS (Jago et al., 2007).

With AMS, cows can either have free access to milking (free traffic) or being forced or guided to access another resource (i.e., water, feed, resting) before reaching the AMS. Regardless of the type of traffic system, diurnal patterns of feeding and lying behaviors persist in AMS, with fewer cows feeding and more cows lying down during the night (DeVries et al., 2011; Jacobs, 2011; Munksgaard et al., 2011). Imposing a forced or guided traffic to cows milked in an AMS improves milking frequency and reduces variation in milking intervals, but it has been reported to reduce the time that cows have access to the feed bunk (Hermans et al., 2003; Woolford et al., 2004; Melin et al., 2007) and compromise feed intake (Bach et al., 2009). In fact, a recent multivariate analysis of field data (Tremblay et al., 2016) reported that forced traffic was associated with decreased milk production compared with free traffic conditions. Therefore, the ideal situation would be free traffic and nutritional approaches that would reduce variation in the number of visits to the AMS. However, because the number of daily visits per cow to the AMS is also dependent on many other factors, other considerations, such as stage of lactation or group composition, should be considered. For instance, primiparous cows visit the AMS more often than multiparous cows (Bach et al., 2006), and the number of visits to an AMS seems to reach a maximum plateau around 100 DIM (Clark et al., 2014). In an AMS, cows need to attend the feeder and the milking system individually, which is an unnatural behavior because dairy cows are gregarious and show marked synchronized behaviors (Benham, 1982). 
Dominant cows spend less time in the waiting area than subordinate cows (Melin et al., 2005); thus, milking frequency of subordinate cows is typically lower than that of dominant cows (Melin et al., 2006; Halachmi, 2009) and negative social interactions at the waiting area of the AMS may reduce the motivation of cows to revisit the AMS a second time (Jacobs et al., 2012). When milking cows in an AMS, some disputes between cows to gain access to feed may occur, which in turn may diminish lying times of the cows that engage in conflicts and those that peacefully wait to access the feeder. Furthermore, the repercussions of social hierarchy seem to be more relevant under forced or guided than under free traffic conditions (Hermans et al., 2003; Rodenburg, 2012), and forced traffic may compromise resting times of cows (Thune et al., 2002).

Another behavioral aspect to consider when designing the nutritional program for an AMS is the feeding patterns of cows. In production systems that are closer to natural conditions (e.g., grazing), cows express a crepuscular feeding pattern, with a large proportion of feed consumed at dawn and dusk (reviewed by Albright, 1993); under confinement conditions, however, feeding patterns are greatly influenced by milking and feed delivery times (DeVries et al., 2003; Mäntysaari et al., 2006). Deming et al. (2013) reported that cows fed a PMR twice daily visited the AMS about $2 \mathrm{~h}$ closer to each feed delivery time than cows fed once a day, which would indicate that delivering PMR is a strong motivating stimulus for cows to visit the AMS (under free traffic conditions). Contrary to what would occur in a herd equipped with a conventional milking parlor, where cows are milked consistently at the same time every day, in an AMS, milking times for each cow may change considerable from day to day. It has been shown that cows subjected to 4- and 6-h feeding periods were able to learn each routine and adapt the timing of their movement to, and from, the feed bunk to match the duration of the feeding period applied (Livshin et al., 1995). Thus, if feed were to be provided during milking, in a conventional herd cows could anticipate they would be fed in the parlor and could adapt their eating pattern to accommodate that meal. In an AMS, however, the fluctuations in milking and eating patterns, especially under forced or guided traffic conditions, make it difficult for the cow to maintain a constant intake of PMR and concentrate in the AMS and keeping the proportion of forage to concentrate in the total diet constant. In summary, from a behavioral standpoint, free traffic conditions coupled with frequent deliveries of the PMR at the feed bunk and limiting concentrate allowance in the AMS to 3 to $4 \mathrm{~kg} / \mathrm{d}$ seem more beneficial for milking cows in a AMS.

\section{NUTRITIONAL ASPECTS}

Concentrate feeding at the AMS is considered to be the most effective strategy for attracting cows to milking and minimize fetching, because cows, if given a choice, will choose feeding over milking (Prescott et al., 1998). A common feeding strategy on many dairy farms equipped with AMS is to start with a low level of concentrates at calving, followed by a linear increase during the first weeks of lactation (Kokkonen et al., 2004). Around lactation peak, from wk 3 until 10 to 14 , concentrate supply increases as milk yield increases and, after that, concentrate allowance is lowered following the decline in milk yield (André et al., 2010). The ideal quantity of concentrate to be offered at the AMS is not clear, but, in general, cows do not consume all the concentrate that is allocated in the AMS when concentrate allowances are high (i.e., $>4 \mathrm{~kg} / \mathrm{d}$ ); the amount of unconsumed concentrate seems to increase as concentrate allowance increases (Figure 1), making the system less precise in terms of providing the exact nutrient requirements to each cow, although the cow could obtain some of the nutrients by consuming more PMR. These deviations in feed intake between days may carry some negative consequences beyond those associated with inconsistent milking frequency. Variation in nutrient supply, per se, has been shown to negatively affect milk production. McBeth et al. (2013) reported that changes in the DM content in a TMR, due to variations in moisture content of its corn silage, had negative effects on DMI and milk yield, and Sova et al. (2014) described a negative relationship between the coefficient of variation of $\mathrm{NE}_{\mathrm{L}}$ content of a TMR and milk production across 22 surveyed dairy herds. In addition, large concentrate allowances in the AMS are typically coupled with feeding a PMR with a low nutrient density; thus, if cows do not consume all concentrate allocated in the AMS, their nutrient supply is compromised, which could hamper milk production and profits. In fact, Tremblay et al. (2016) found a negative association between concentrate allowance in the AMS and milk yield, although the same study also reported a positive association between the percentage of feed allowance that was not consumed and milk production. This emphasizes that the potential advantages of feeding cows more closely to their nutrient needs are only achieved if the precision at which these nutrients are offered is high. White and Capper (2014) evaluated the potential benefits of using precision nutrition by formulating TMR more frequently for herd milking in conventional parlors in different climates and concluded that large economic benefits could be attained, but that these were dependent on the degree of actual 


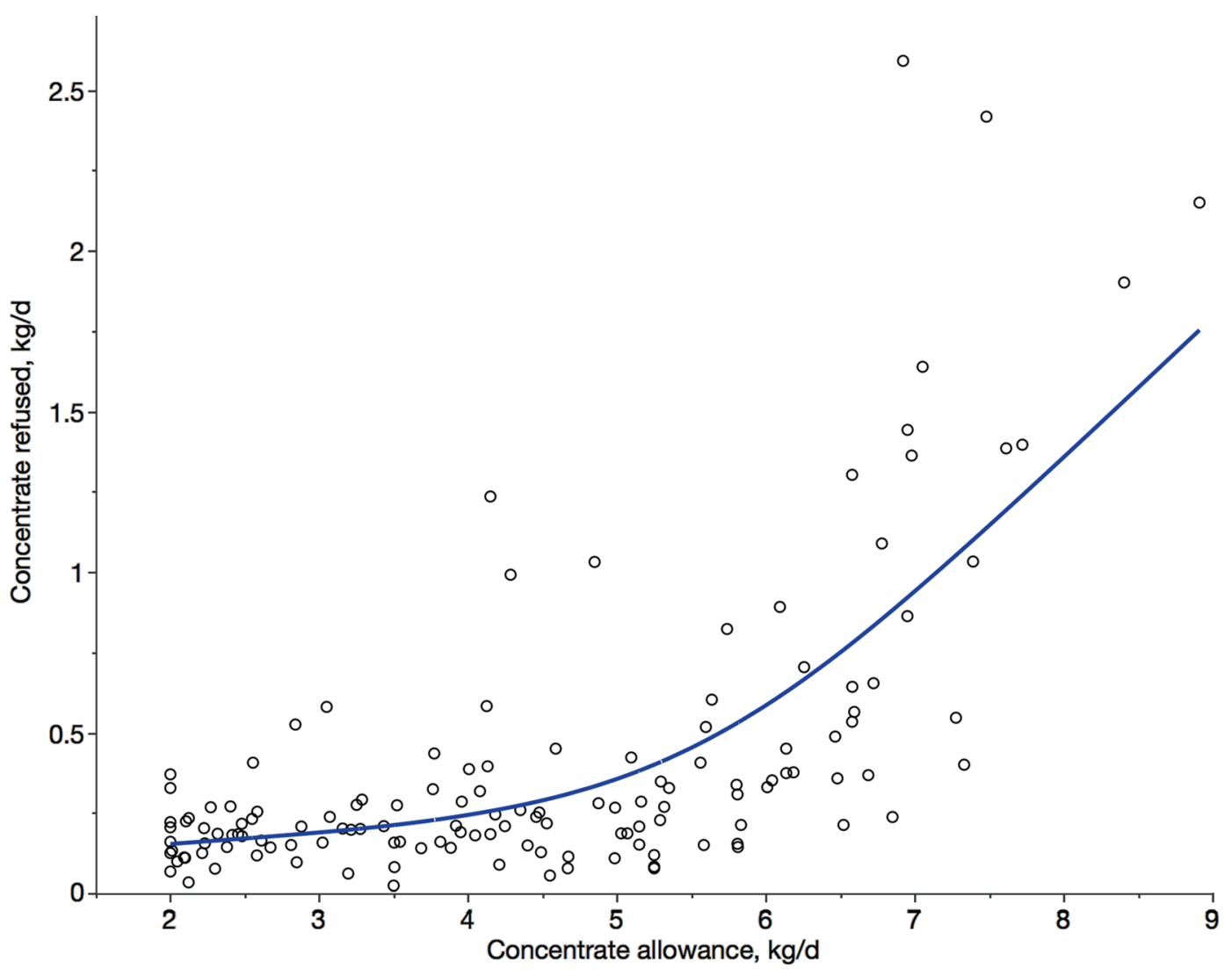

Figure 1. Evolution of the amount of concentrate unconsumed (average over an 8-d period) relative to the amount of concentrate offered (average over a 7 -d period) in an automatic milking system. Color version available online.

precision or margin of error during the provision (mixing and delivery) of nutrients to the cows.

Another reason for limiting concentrate supply in the AMS is the time constraint that cows will face when attempting to consume their entire concentrate allowance. Cows typically consume TMR and PMR at a rate ranging between 50 and $150 \mathrm{~g} / \mathrm{min}$ (Bach et al., 2007a, 2009; DeVries et al., 2009) and pellet concentrates between 250 and $400 \mathrm{~g} / \mathrm{min}$ (Kertz et al., 1981). Considering an average time spent in the AMS per milking of about 7 min (Castro et al., 2012), cows could consume at most an average of about $2.8 \mathrm{~kg}$ of concentrate per milking. Because on most occasions the average number of visits to an AMS is $<3 /$ d [cows averaged 2.8 milkings/d in Deming et al. (2013); 2.4 milkings/d in Wagner-Storch et al. (2003); and 2.2 milkings/d in Bach et al. (2009)], a cow could consume a theoretical maximum average of $8.4 \mathrm{~kg}$ of concentrate per day. Therefore, using concentrate allowances $>8 \mathrm{~kg} / \mathrm{d}$ are likely to fail, and to take advantage of precision feeding approaches (as discussed later) in AMS the amount of concentrate allowance should be kept low (i.e., $<4 \mathrm{~kg} / \mathrm{d}$ ).

Besides limiting the amount of concentrate offered in an AMS to ensure consistency in nutrient supply across days, nutrient composition of the concentrate is also important. For example, feeding concentrates with a high content of starch may not only affect appetite and feeding behavior of the cows, but also the rate and extent of NDF digestibility and rumen $\mathrm{pH}$, which may in turn alter milk composition and production as well as increase the risk of lameness (Oba and Wertz-Lutz, 2011). Prevention of lameness is important in herds with AMS because lame cows voluntarily approach the AMS less frequently (Bach et al., 2006; Borderas et al., 2008) and additional labor is required to fetch lame cows for milking (Bach et al., 2007a). Regarding milk production and composition, Miron et al. (2004) reported that feeding concentrates high in starch content increased milk protein content and feeding concentrates rich in digestible fiber (e.g., soybean hulls) increased milk fat content. A more recent study (Madsen et al., 2010) reported increases in milking frequency and changes in milk composition when feeding about $5 \mathrm{~kg} / \mathrm{d}$ of concentrates with different nutrient profiles in an AMS. On the other hand, Halachmi et al. (2006) compared 2 concentrates (25 vs. $49 \%$ starch) and reported similar numbers of voluntary milkings (3.31 vs. 3.39 visits/cow per day), milk yield, and milk components. The differ- 
ence in these 2 studies was, mainly, that Miron et al. (2004) used $8 \mathrm{~kg} / \mathrm{d}$ of concentrate allowance, whereas Halachmi et al. (2006) limited concentrate allowance to $3 \mathrm{~kg} / \mathrm{d}$. Thus, it can be inferred that if concentrate allowance is kept low (i.e., $3 \mathrm{~kg} / \mathrm{d}$ ), nutrient composition of the concentrate at the AMS has minor repercussions on yield, milk composition, and number of visits to the AMS.

In addition of the chemical composition of the concentrate offered in the AMS, the physical form and the palatability of the ingredients used may also determine intake and regularity of visits to the AMS. Madsen et al. (2010) concluded that cows would prefer concentrates based on a mixture of barley and oats, and that cows would prefer wheat over corn or barley. Also, in some circumstances, increasing the palatability of concentrates fed in an AMS through addition of flavoring and appetizing substances during 4 wk has been shown to increase the number of visits to the AMS (Migliorati et al., 2010), even when low concentrate allowances (1.5 to $3.5 \mathrm{~kg} / \mathrm{d}$ ) were offered. A more recent study (Harper et al., 2016) reported no changes in feed intake and visit patterns to the AMS when offering a concentrate flavored with fenugreek or vanilla. Regarding the physical form of the concentrate offered at the AMS, a pellet form is preferred over mash or meal form (Spörndly and Asberg, 2006). Also, the hardness of the pellet should be high as crumbles and fines diminish intake of dairy cows (Rodenburg et al., 2004).

Another aspect to consider is the supply of minerals and vitamins with AMS. Typically, these components are considered to have poor acceptability by cows and most producers exclude them from the concentrate for the AMS and are only supplied through the PMR. However, as milk yield increases and concentrate allowance at the AMS is also increased, the amount of minerals that the cow will consume might be limited because the increase in DMI is mainly driven by an increase in concentrate intake rather than PMR intake. For instance, from the study of Bach et al. (2007), which evaluated milk and intake responses in cows milked in an AMS and offered either 3 or $8 \mathrm{~kg}$ of concentrate/d, it can be calculated that for every unit increase in concentrate intake at the AMS there was a concomitant reduction in PMR consumption equivalent to 1.15 units. This substitution rate of concentrate for PMR can even be more important when AMS are installed in grazing herds. Cows milked in conventional milking parlors with access to pasture typically reduce their grazing time by 12 min (presumably reducing their pasture consumption) for every $1 \mathrm{~kg}$ of concentrate consumed (Bargo et al., 2003; Sheahan et al., 2011).

Automatic milking systems bring an interesting opportunity to feed cows using a precision feeding approach. Precision feeding has the potential to improve productivity and, most importantly, efficiency of production by meeting each individual cow's nutrient requirements accurately (Cerosaletti et al., 2004; Gehman, 2011). The AMS technology bears the appealing opportunity of overcoming the inefficiencies linked to TMR or PMR feeding, where cows are fed to an average production and some cows receive less and others more nutrients than what they need. Feeding a TMR offers the great advantage of simplicity, as it allows feeding large numbers of cows in groups in an easy manner under the assumption that, with TMR, each mouthful of feed the cow consumes contains a balanced combination of nutrients, and these differences in milk production across cows can be overcome by changes in DMI. However, because cows do sort (Leonardi and Armentano, 2007), the composition of the TMR actually changes throughout the day (Kononoff and Heinrichs, 2003), and the theoretically balanced nutrient profile of the TMR may become imbalanced. Furthermore, cows need to consume both a balanced-nutrient meal and the right amount of it. In other words, because intake is variable between cows, and also within cows depending on stage of lactation, BW, and so on, a balanced mouthful of a TMR for one cow may be an imbalanced mouthful for another cow in the same pen. For example, according to the NRC (2001), a cow producing $27 \mathrm{~kg}$ of milk per day needs $38 \mathrm{Mcal}$ of $\mathrm{NE}_{\mathrm{L}} / \mathrm{d}$ and about $3.2 \mathrm{~kg}$ of $\mathrm{CP} / \mathrm{d}$. A cow with such a level of milk production would consume $20.6 \mathrm{~kg} / \mathrm{d}$; thus, the TMR should have a nutrient density of $1.44 \mathrm{Mcal}$ of $\mathrm{NE}_{\mathrm{L}} / \mathrm{kg}$ and $15.4 \% \mathrm{CP}$. If that TMR were consumed by a cow producing $30 \mathrm{~kg}$ of milk per day, DMI would increase by $1 \mathrm{~kg}$ and she would need additional 2 Mcal of $\mathrm{NE}_{\mathrm{L}}$ and $103 \mathrm{~g}$ of additional MP. If she consumes $21.6 \mathrm{~kg}$ of the TMR balanced for $27 \mathrm{~kg}$ of milk per day, she would consume 1.42 additional Mcal (while needing 2 additional Mcal) and 35 additional grams of MP (while needing additional $103 \mathrm{~g}$ ). Thus, energy and protein balance progressively differ at different proportions as milk production deviates from the one for which the ration was originally balanced (Figure 2).

Implementing precision feeding strategies with AMS (and in other situations, such as parlor feeding) bears the challenge of estimating (and monitoring) the expected milk response obtained for any given concentrate supplementation. The efficiency at which the concentrate will be used to produce milk is a driver for profit, and thus, if milk yield response is below expectations, supplementing concentrates may not be a profitable decision, especially if milk prices are low and feed costs are high. Maltz et al. $(1991,1992)$ evaluated 2 different strategies for supplementing concentrates to cows in comparison with feeding a TMR. The first 
strategy was based on the rule that $1 \mathrm{~kg}$ of concentrate corresponded to $2 \mathrm{~kg}$ of milk. The second strategy accounted for changes in BW in addition to milk yield. However, both strategies were inconclusive regarding the potential superiority of individual supplementation of concentrates versus TMR feeding. A few studies have attempted to forecast milk performance responses to concentrate supplementation (Deluyker et al., 1990; Woods et al., 2003; André et al., 2011). Because milking responses depend on many factors (e.g., environment, stage of lactation, nutrient composition of the concentrate offered, or parity), predicting models tend to be complicated and difficult to implement in practice (André et al., 2011). Nevertheless, a more practical (although reactive instead of proactive) approach for controlling profit can involve monitoring animal response and then making a decision on whether the concentrate supplementation is profitable. However, the implementation of these precision feeding strategies using an individual dynamic approach is only useful if there is sufficient variation between individual responses and if the economic environment is encouraging. However, André et al. (2010) concluded that individual variation in milk responses to concentrate supplementation is sufficient to justify precision feeding and attempting to improve economic results during early lactation, but it was not clear at later stages of lactation.

Most AMS systems are equipped with a single bin for delivering concentrate to cows. Under this situation, as it would occur with TMR, the AMS offers a feed with a fixed chemical and nutritional composition with the only variable in the system being the amount of concentrate that each cow is entitled to consume on a daily basis. Thus, depending on the nutrient density of the PMR, the stage of lactation, and milk production, cows receive different amounts of feed but, as described above, the composition of the pellet or mash offered is the same regardless of the amount of milk produced; thus, nutrient supply progressively becomes imbalanced as milk yield deviates from the one used to formulate the feed supplement. An interesting opportunity to maximize returns from an AMS is the use of a combination of feeds (e.g., an energy source and a protein source) and feed them to cows at different proportions and quantities according to milk yield, BW, stage of lactation, and even milk components with some systems. However, a potential caveat when using precision feeding technologies in an AMS is that

\section{MP, $\mathrm{kg} / 10 \mathrm{~kg} \square \mathrm{DMl}, \mathrm{kg} / \mathrm{d} \square \mathrm{MP}, \mathrm{hg} / \mathrm{d} \square \mathrm{Mcal} / \mathrm{kg} \square \mathrm{Mcal} / \mathrm{d}$}

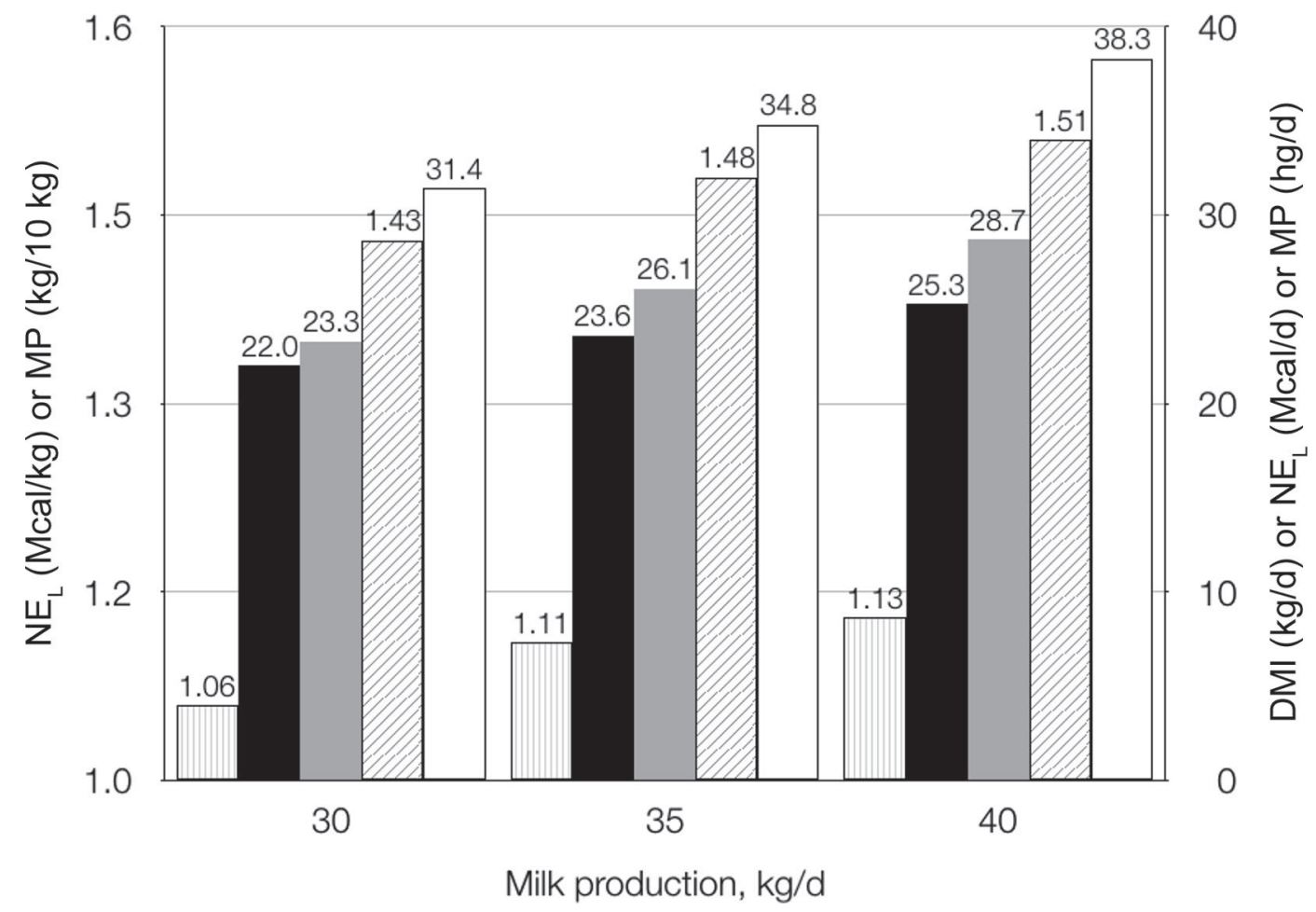

Figure 2. Dry matter intake, $\mathrm{MP}$, and $\mathrm{NE}_{\mathrm{L}}$ for different milk yields according to the $\mathrm{NRC}(2001)$. The proportion of $\mathrm{MP}$ and $\mathrm{NE}_{\mathrm{L}}$ in the total diet is not constant and increases at different rates for $\mathrm{MP}$ and $\mathrm{NE}_{\mathrm{L}}$ as milk yield increases. 
cows, despite their theoretical needs for nutrients, may opt for not consuming the amount of feed allocated and delivered to them. In the AMS, that represents a lost opportunity to sustain production and a loss of feed and money, because once the cow is identified and received the calculated amount, at the end of the milking any unconsumed feed is discarded or consumed by another cow. This type of situation can be minimized by limiting meal sizes to about 1.0 to $1.5 \mathrm{~kg}$ per visit.

It should be borne in mind that, although the application of precision technologies has resulted in improvements in production and profitability, to fully capture the advantages of precision alternatives it is pivotal to devote attention toward pivotal aspects of dairy production, such as adequate PMR mixing and formulation, accurate monitoring of moisture and nutrient contents of feeds, stocking density, feed bunk management, and so on. For instance, Cook (2008) reported that about $30 \%$ of the variation in DMI could be explained by dietary factors, with the remaining $70 \%$ being attributed to nondietary factors. Similarly, Bach et al. (2008) reported that key management aspects, such as age at first calving, amount of feed refusals, number of feed pushups, and stocking density, explained more than $55 \%$ of the variation in milk production in 47 herds that were feeding exactly the same TMR. Therefore, if a herd has management problems, the adoption of precision technologies per se is unlikely to solve them; similarly, if maximum benefits from AMS are aimed, all fundamental management aspects of dairy production need to be carefully implemented.

\section{ECONOMIC CONSIDERATIONS}

From an economic efficiency perspective, the main target is maximizing milk production per AMS (Sonck and Donkers, 1995). Milk harvested per cow and milking is related to the time elapsed since previous milking, with this relationship being more or less linear until $16 \mathrm{~h}$ and becomes constant thereafter (Delamaire and GuinardFlament, 2006). Tremblay et al. (2016) showed that, as the number of cows per AMS increases, the number of milkings is reduced (i.e., milking interval increases) and the time that cows occupy the AMS increases. Despite the fact that both milking frequency and time spent in the AMS per milking increase milk production, these 2 aspects rarely increase simultaneously (Tremblay et al., 2016). It is commonly recommended that the number of animals per AMS should be around 60 to 70 cows. This number stems from the time required to clean the AMS, unit attachment failures, periods of nonattendance, and technical maintenance, which leaves around 20 to $22 \mathrm{~h} / \mathrm{d}$ of available time for milking (Halachmi, 2004; Lyons et al., 2014), and because a single AMS has a limited capacity of around 8 milkings/h (Ketelaarde Lauwere et al., 2000), leading to a theoretical total number of cows that can be milked 2.5 times every day between 60 and 70 cows. Results from the literature suggest that, to attain maximum milk harvesting capacity of an AMS, the goal should be maximizing milk yield per cow instead of increasing the number of cows. Typically, decreasing the number of cows per AMS decreases the time cows spend waiting in the premilking area, particularly for low socially ranked or less experienced cows (Halachmi, 2009); likewise, small reductions in cow numbers are commonly compensated by increases in milk production from the remaining cows because the number of milkings increase and time spent milking decreases, especially when cows are selected for high milking speed (Tremblay et al., 2016).

To support the maximum possible milk yield, however, the economic return from the feed needs to be accounted for. Feed represents 50 to $70 \%$ of all costs in dairy production (Bozic et al., 2012); therefore, increasing feed efficiency has a major effect on profitability. Furthermore, improving feed efficiency has positive consequences for the environment (Reed et al., 2015). Economic returns when milking cows in an AMS could be improved if a dynamic feeding approach was implemented; that is, combining 2 concentrates (i.e., energy and protein) or more at the AMS in different amounts and proportions. Precision feeding provides, in theory, only the exact amount of nutrient required because the supplement changes in composition as needed, whereas conventional supplementation, because of a fixed profile of nutrients, provides some of those in excess without additional benefits and incurring in economic inefficiencies.

\section{IMPLICATIONS}

Milking and feeding times for cows in herds equipped with AMS are not as consistent as those found in herds using conventional parlors. Many factors influence the regularity of cow visits to the AMS. Among these, the type and amount of concentrate used and the type and routine of PMR delivery are most important. Forced traffic ensures a greater and more consistent number of visits to the AMS, but it may hamper or limit milk production due to impaired intake of the PMR; thus, free traffic is preferred. Restricting concentrate allowance to $<3$ to $4 \mathrm{~kg} / \mathrm{d}$ is recommended to maximize economic returns and minimize variation in nutrient intake. By keeping concentrate allowance low, potential digestion upsets are avoided, total feed costs are reduced, consistency of milking frequency increases, and amount of concentrate refusals decreases. An interesting, and effective, approach to improve economic returns with 
AMS consists of using a combination of multiple concentrates (both in terms of total amount and proportion) to precisely meet nutrient requirements of each cow in the herd.

\section{ACKNOWLEDGMENTS}

This work was partially supported by the CERCA Programme from Generalitat de Catalunya (Barcelona, Spain), and a fellowship from the OECD Co-operative Research Programme: Biological Resource Management for Sustainable Agricultural Systems (Paris, France) in 2016 to V. E. Cabrera.

\section{REFERENCES}

Albright, J. L. 1993. Feeding behavior of dairy cattle. J. Dairy Sci. 76:485-498.

André, G., P. B. M. Berentsen, G. van Duinkerken, B. Engel, and A. G. J. M. O. Lansink. 2010. Economic potential of individual variation in milk yield response to concentrate intake of dairy cows. J. Agric. Sci. 148:263-276.

André, G., B. Engel, P. B. M. Berentsen, G. van Duinkerken, and A. G. J. M. O. Lansink. 2011. Adaptive models for online estimation of individual milk yield response to concentrate intake and milking interval length of dairy cows. J. Agric. Sci. 149:769-781.

Bach, A., and I. Busto. 2005. Effects on milk yield of milking interval regularity and teat cup attachment failures with robotic milking systems. J. Dairy Res. 72:101-106.

Bach, A., M. Devant, C. Igleasias, and A. Ferrer. 2009. Forced traffic in automatic milking systems effectively reduces the need to get cows, but alters eating behavior and does not improve milk yield of dairy cattle. J. Dairy Sci. 92:1272-1280.

Bach, A., M. Dinarés, M. Devant, and X. Carré. 2007b. Associations between lameness and production, feeding and milking attendance of Holstein cows milked with an automatic milking system. J. Dairy Res. 74:40-46.

Bach, A., C. Iglesias, S. Calsamiglia, and M. Devant. 2007a. Effect of amount of concentrate offered in automatic milking systems on milking frequency, feeding behavior, and milk production of dairy cattle consuming high amounts of corn silage. J. Dairy Sci. 90:5049-5055.

Bach, A., C. Iglesias, M. Devant, and N. Ràfols. 2006. Performance and feeding behavior of primiparous cows loose housed alone or together with multiparous cows. J. Dairy Sci. 89:337-342.

Bach, A., N. Valls, A. Solans, and T. Torrent. 2008. Associations between nondietary factors and dairy herd performance. J. Dairy Sci. 91:3259-3267.

Bargo, F., L. D. Muller, E. S. Kolver, and J. E. Delahoy. 2003. Invited review: Production and digestion of supplemented dairy cows on pasture. J. Dairy Sci. 86:1-42.

Benham, P. F. J. 1982. Synchronization of behaviour in grazing cattle. Appl. Anim. Ethol. 8:403-404.

Borderas, T. F., A. Fournier, J. Rushen, and A. M. B. de Passillé. 2008. Effect of lameness on dairy cows' visits to automatic milking systems. Can. J. Anim. Sci. 88:1-8.

Bozic, M., J. Newton, C. S. Thraen, and B. W. Gould. 2012. Meanreversion in income over feed cost margins: Evidence and implications for managing margin risk by US dairy producers. J. Dairy Sci. 95:7417-7428.

Castro, A., J. M. Pereira, C. Amiama, and J. Bueno. 2012. Estimating efficiency in automatic milking systems. J. Dairy Sci. 95:929-936.

Cerosaletti, P. E., D. G. Fox, and L. E. Chase. 2004. Phosphorus reduction through precision feeding of dairy cattle. J. Dairy Sci. $87: 2314-2323$.
Clark, C. E. F., N. B. P. Kwinten, D. A. J. M. van Gastel, K. L. Kerrisk, N. A. Lyons, and S. C. Garcia. 2014. Differences in voluntary cow traffic between Holstein and Illawarra breeds of dairy cattle in a pasture-based automatic milking system. Asian-australas. J. Anim. Sci. 27:587-591.

Cook, N. B. 2008. Makin' me dizzy-Pen moves and facility designs to maximize transition cow health and productivity. Proc. Vermont Large Farm Dairy Conference. Colchester, VT. February 26, 2008. Vermont Dairy Producers Association, Burlington.

de Koning, C. 2011. Automatic milking: Common practice on over 10,000 dairy farms worldwide. Pages 14-31 in Proceedings of the Dairy Research Foundation Symposium, 6-7 July 2011, Camden, Australia. University of Sydney, Camden, Australia.

Delamaire, E., and J. Guinard-Flament. 2006. Longer milking intervals alter mammary epithelial permeability and the udder's ability to extract nutrients. J. Dairy Sci. 89:2007-2016.

Deluyker, H. A., R. H. Shumway, W. E. Wecker, A. S. Azari, and L. D. Weaver. 1990. Modeling daily milk yield in Holstein cows using time series analysis. J. Dairy Sci. 73:539-548.

Deming, J. A., R. Bergeron, K. E. Leslie, and T. J. DeVries. 2013 Associations of cow-level factors, frequency of feed delivery, and standing and lying behaviour of dairy cows milked in an automatic system. Can. J. Anim. Sci. 93:427-433.

DeVries, T. J., K. A. Beauchemin, F. Dohme, and K. S. SchwartzkopfGenswein. 2009. Repeated ruminal acidosis challenges in lactating dairy cows at high and low risk for developing acidosis: Feeding, ruminating, and lying behavior. J. Dairy Sci. 92:5067-5078.

DeVries, T. J., J. A. Deming, J. Rodenburg, G. Seguin, K. E. Leslie, and H. W. Barkema. 2011. Association of standing and lying behavior patterns and incidence of intramammary infection in dairy cows milked with an automatic milking system. J. Dairy Sci. 94:3845-3855.

DeVries, T. J., M. A. G. von Keyserlingk, and K. A. Beauchemin. 2003. Short communication: Diurnal feeding pattern of lactating dairy cows. J. Dairy Sci. 86:4079-4082.

Gehman, A. M. 2011. Enhanced nitrogen utilisation in dairy cattle with precision protein nutrition. Rec. Adv. Anim. Nutr. 18:187195

Gygax, L., I. Neuffer, C. Kaufmann, R. Hauser, and B. Wechsler. 2007. Comparison of functional aspects in two automatic milking systems and auto-tandem milking parlors. J. Dairy Sci. 90:4265-4274.

Halachmi, I. 2004. The automatic milking farm in a hot climate. J. Dairy Sci. 87:764-775.

Halachmi, I. 2009. Simulating the hierarchical order and cow queue length in an automatic milking system. Biosyst. Eng. 102:453-460.

Halachmi, I., S. Ofir, and J. Miron. 2005. Comparing two concentrate allowances in an automatic milking system. Anim. Sci. 80:339-343.

Halachmi, I., E. Shoshani, R. Solomon, E. Maltz, and J. Miron. 2006. Feeding of pellets rich in digestible neutral detergent fiber to lactating cows in an automatic milking system. J. Dairy Sci. 89:32413249 .

Harper, M. T., J. Oh, F. Giallongo, J. C. Lopes, H. L. Weeks, J. Faugeron, and A. N. Hristov. 2016. Short communication: Preference for flavored concentrate premixes by dairy cows. J. Dairy Sci. 99:6585-6589.

Hermans, G. G. N., A. H. Ipema, J. Stefanowska, and J. H. M. Metz. 2003. The effect of two traffic situations on the behavior and performance of cows in an automatic milking system. J. Dairy Sci. 86:1997-2004.

Jacobs, J. A. 2011. Dairy cow adaptation to and interaction with an automatic milking system. MS Thesis. Department of Animal Science, Michigan State University, East Lansing.

Jacobs, J. A., K. Ananyeva, and J. M. Siegford. 2012. Dairy cow behavior affects the availability of an automatic milking system. J. Dairy Sci. 95:2186-2194.

Jago, J. G., K. L. Davis, P. J. Copeman, I. Ohnstad, and M. M. Woolford. 2007. Supplementary feeding at milking and minimum milking interval effects on cow traffic and milking performance in a pasture-based automatic milking system. J. Dairy Res. 74:492-499. 
Kertz, A. F., B. K. Darcy, and L. R. Prewitt. 1981. Eating rate of lactating cows fed four physical forms of the same grain ration. J. Dairy Sci. 64:2388-2391.

Ketelaar-de Lauwere, C. C., A. H. Ipema, C. Lokhorst, J. H. M. Metz, J. P. T. M. Noordhuizen, W. G. P. Schouten, and A. C. Smits 2000. Effect of sward height and distance between pasture and barn on cows' visits to an automatic milking system and other behaviour. Livest. Prod. Sci. 65:131-142.

Kokkonen, T., A. Tesfa, M. Tuori, and L. Syrjälä-Qvist. 2004. Concentrate feeding strategy of dairy cows during transition period. Livest. Prod. Sci. 86:239-251.

Kononoff, P. J., and A. J. Heinrichs. 2003. The effect of corn silage particle size and cottonseed hulls on cows in early lactation. J. Dairy Sci. 86:2438-2451.

Leonardi, C., and L. E. Armentano. 2007. Short communication: Feed selection by dairy cows fed individually in a tie-stall or as a group in a free-stall barn. J. Dairy Sci. 90:2386-2389.

Livshin, N., E. Maltz, and Y. Edan. 1995. Regularity of dairy cow feeding behavior with computer-controlled feeders. J. Dairy Sci. 78:296-304.

Lyons, N. A., K. L. Kerrisk, and S. C. Garcia. 2014. Milking frequency management in pasture-based automatic milking systems: A review. Livest. Sci. 159:102-116.

Madsen, J., M. R. Weisbjerg, and T. Hvelplund. 2010. Concentrate composition for automatic milking systems - Effect on milking frequency. Livest. Sci. 127:45-50.

Maltz, E., O. Kroll, S. L. Spahr, S. Devir, A. Genizi, and R. Sagi. 1991 Milk yield, parity, and cow potential as variables for computerized concentrate supplementation strategy. J. Dairy Sci. 74:2277-2289.

Maltz, E., S. Devir, O. Kroll, B. Zur, S. L. Spahr, and R. D. Shanks. 1992. Comparative responses of lactating cows to total mixed rations or computerized individual concentrates feeding. J. Dairy Sci. 75:1588-1603.

Mäntysaari, P., H. Khalili, and J. Sariola. 2006. Effect of feeding frequency of a total mixed ration on the performance of high-yielding dairy cows. J. Dairy Sci. 89:4312-4320.

McBeth, L. R., N. R. St-Pierre, D. E. Shoemaker, and W. P. Weiss. 2013. Effects of transient changes in silage dry matter concentration on lactating dairy cows. J. Dairy Sci. 96:3924-3935.

Melin, M., G. Hermans, G. Pettersson, and H. Wiktorsson. 2006. Cow traffic in relation to social rank and motivation of cows in an automatic milking system with control gates and an open waiting area. Appl. Anim. Behav. Sci. 96:201-214.

Melin, M., G. Pettersson, K. Svennersten-Sjaunja, and H. Wiktorsson. 2007. The effects of restricted feed access and social rank on feeding behavior, ruminating and intake for cows managed in automated milking systems. Appl. Anim. Behav. Sci. 107:13-21.

Melin, M., H. Wiktorsson, and L. Norell. 2005. Analysis of feeding and drinking patterns of dairy cows in two cow traffic situations in automatic milking systems. J. Dairy Sci. 88:71-85.

Migliorati, L., M. Speroni, S. Lolli, and F. Calza. 2010. Effect of concentrate feeding on milking frequency and milk yield in an automatic milking system. Ital. J. Anim. Sci. 4(Suppl. 2):221-223.

Miron, J., M. Nikbachat, A. Zenou, and D. Ben-Ghedalia. 2004. Lactation performance and feeding behavior of dairy cows supplemented via automatic feeders with soy hulls or barley based pellets. J. Dairy Sci. 87:3808-3815.

Munksgaard, L., J. Rushen, A. M. de Passillé, and C. C. Krohn. 2011. Forced versus free traffic in an automated milking system. Livest. Sci. 138:244-250.

NRC. 2001. Nutrient Requirements of Dairy Cattle. 7th rev. ed. Natl. Acad. Press, Washington, DC.

Oba, M., and A. E. Wertz-Lutz. 2011. Ruminant nutrition symposium Acidosis: New insights into the persistent problem. J. Anim. Sci. 89:1090-1091.

Prescott, N., T. Mottram, and A. Webster. 1998. Relative motivations of dairy cows to be milked or fed in a Y-maze and an automatic milking system. Appl. Anim. Behav. Sci. 57:23-33.

Reed, K. F., L. E. Moraes, D. P. Casper, and E. Kebreab. 2015. Predicting nitrogen excretion from cattle. J. Dairy Sci. 98:3025-3035.
Rodenburg, J. 2012. The impact of robotic milking on milk quality, cow comfort and labor issues. Pages $126-137$ in Natl. Mastitis Counc. Annu. Meet. Proc. St. Pete Beach, FL. Natl. Mastitis Counc. Madison, WI.

Rodenburg, J., E. Focker, and K. Hand. 2004. Effect of the composition of concentrate fed in the milking box on milking frequency and voluntary attendance in automatic milking systems. Pages 511- 512 in A Better Understanding of Automatic Milking. A. Meijering, H. Hogeveen, and C. J. A. M de Koning, ed. Wageningen Academic Publishers, Wageningen, the Netherlands.

Rodenburg, J., and H. K. House. 2007. Field observations on barn layout and design for robotic milking of dairy cows. In Proc. 6th Int. Dairy Housing Conf., Publication Number 701P057e (electronic only). American Society of Agricultural and Biological Engineers, St. Joseph, MI.

Scott, V. E., P. C. Thomson, K. L. Kerrisk, and S. C. Garcia. 2014 Influence of provision of concentrate at milking on voluntary cow traffic in a pasture-based automatic milking system. J. Dairy Sci. 97:1481-1490

Sheahan, A. J., E. S. Kolver, and J. R. Roche. 2011. Genetic strain and diet effects on grazing behavior, pasture intake, and milk production. J. Dairy Sci. 94:3583-3591.

Sonck, B. R., and H. W. J. Donkers. 1995. The milking capacity of a milking robot. J. Agric. Eng. Res. 62:25-38.

Sova, A. D., S. J. LeBlanc, B. W. Mcbride, and T. J. DeVries. 2014 Accuracy and precision of total mixed rations fed on commercial dairy farms. J. Dairy Sci. 97:562-571.

Spörndly, E., and T. Asberg. 2006. Eating rate and preference of different concentrate components for cattle. J. Dairy Sci. 89:2188-2199.

Spörndly, E., and E. Wredle. 2002. The effect of distance to pasture and level of supplementary feeding on visiting frequency, milk production and live weight of cows in an automatic milking system. Proceedings of the First North American Conference on Robotic Milking. Toronto, ON. March 2002.

Steeneveld, W., L. W. Tauer, H. Hogeveen, and A. G. J. M. O. Lansink. 2012. Comparing technical efficiency of farms with an automatic milking system and a conventional milking system. J. Dairy Sci. 95:7391-7398.

Stefanowska, J., M. Plavsic, A. H. Ipema, and M. M. W. B. Hendriks. 2000. The effect of omitted milking on the behaviour of cows in the context of cluster attachment failure during automatic milking. Appl. Anim. Behav. Sci. 67:277-291.

Thune, R. Ø., A. M. Berggren, L. Gravås, and H. Wiktorsson. 2002 Barn layout and cow traffic to optimize the capacity of an automatic milking system. Pages 45-50 in Proc. 1st North Am. Conf. Robotic Milking, Toronto, Canada. J. McLean, M. Sinclair, and B. West, ed. Wageningen Pers, Wageningen, the Netherlands.

Tremblay, M., J. P. Hess, B. M. Christenson, K. K. McIntyre, A. J. Ben Smink, L. G. van der Kamp, de Jong, and D. Döpfer. 2016. Factors associated with increased milk production for automatic milking systems. J. Dairy Sci. 99:3824-3837.

Wagner-Storch, A. M., R. W. Palmer, and D. W. Kammel. 2003. Factors affecting stall use for different freestall bases. J. Dairy Sci. $86: 2253-2266$

White, R. R., and J. L. Capper. 2014. Precision diet formulation to improve performance and profitability across various climates: Modeling the implications of increasing the formulation frequency of dairy cattle diets. J. Dairy Sci. 97:1563-1577.

Woods, V. B., D. J. Kilpatrick, and F. J. Gordon. 2003. Development of empirical models to describe the response in lactating dairy cattle to changes in nutrient intake as defined in terms of metabolisable energy intake. Livest. Prod. Sci. 80:229-239.

Woolford, M. W., R. W. Claycomb, J. Jago, K. Davis, I. Ohnstad, R. Wieliczko, P. Copeman, and K. Bright. 2004. Automatic dairy farming in New Zealand using extensive grazing systems. Pages 280-285 in A Better Understanding of Automatic Milking. A. Meijering, H. Hogeveen, and C. J. A. M. de Koning, ed. Wageningen Academic Publishers, Wageningen, the Netherlands. 